2018 Global Marketing Conference at Tokyo Proceedings: 71-90 (July 2018) https://doi.org/10.15444/GMC2018.01.08.05

\title{
CONCEPTUAL FRAMEWORK FOR MODELING THE AGILE MARKETING CAPABILITY
}

\author{
Ludovica Moi, University of Cagliari, Italy ${ }^{1}$ \\ Francesca Cabiddu, University of Cagliari, Italy \\ Moreno Frau, University of Cagliari, Italy
}

\begin{abstract}
This work aims to deepen how to cope with marketing challenges of XXI century, characterized by turbulent and dynamic environments. Specifically, it explores the theoretical underpinnings to develop an Agile Marketing Capability's framework and propositions. This study performs an in-depth literature review on IT and Dynamic Marketing Capabilities to provide the features, components, functions and types of an Agile Marketing Capability. Given the extreme innovativeness of this topic in marketing realm, it represents a first attempt to understanding the Agile Marketing Capability, which requires further theoretical and empirical contributions and refinements. The framework and propositions of this research may be useful for managers and decision makers to figure out the advantages of the Agile Marketing Capabilities' employment in current marketplaces.
\end{abstract}

Keywords: IT capabilities, dynamic marketing capabilities, agile marketing capability, literature review, theoretical framework

\section{INTRODUCTION}

To handle an era of "digital disruption” (Vassileva, 2017) and develop marketing competencies for stronger competitive advantage and performance (Barrales-Molina, Martínez-López, \& Gázquez-Abad, 2014; Cacciolatti \& Lee, 2016), firms need to adopt more agile approaches in marketing domain (Alford \& Page, 2015). On the one hand, they should leverage on dynamic marketing capabilities (DMCs) to continuously reconfigure their business according to market changes (BarralesMolina et al., 2014). On the other hand, they should exploit IT capabilities (ITCs) in terms of cross-functional integration and organizational flexibility as crucial drivers of these ends (Song, Nason, \& Di Benedetto, 2008). In this context, Agile Marketing is the proper solution to design agile, quick and cost-effective responses to the marketplace (Lu, Ram, Ramamurthy, \& Lubar, 2011). The importance of this topic is quite known in business and project management literature related to software and manufacturing (Miles, 2013; Poolton, Ismail, Reid, \& Arokiam, 2006; Vinodh, Devadasan, Vasudeva Reddy, \& Ravichand, 2010), whereas it is less explored by marketing scholars (Gren, Torkar, \& Feldt, 2015; Hoogveld \& Koster, 2016a, 2016b). Accordingly, it necessitates further theoretical and empirical attention (Hoogveld \& Koster, 2016b; Potdar et al., 2017).

\footnotetext{
${ }^{1}$ ludivic.moi@unica.it
} 
Our aim is to contribute to this debate by examining the role of ITCs in DMCs in the context of Agile Marketing. By performing a systematic literature review of ITCs and DMCs , this study explores the theoretical underpinnings for the Agile Marketing Capability-generating process, and set the bedrocks for future marketing research towards this topic. Indeed, we try to answer to the research question: "what are the key theoretical underpinnings for an Agile Marketing Capability development?”. In section 2, we point out the theoretical background of the Agile Marketing approach; in section 3 and section 4, we accomplish an in-depth literature review on DMCs and ITCs; in section 5, we display a framework and key propositions for an Agile Marketing Capability; in section 6, we end with implications and conclusions.

\section{A THEORETICAL BACKGROUND: THE AGILE MARKETING APPROACH}

Agile Marketing approach arises from Agile Development practices on software realm to respond to customers' needs (Ewel, 2013). In marketing, it implies the development of competencies in providing strategic responses which quickly, costefficiently, flexibly and proactively adapt to market changes (Hendrix, 2014; Poolton et al., 2006; Potdar et al., 2017). According to the literature, Agile Marketing firstly involves omnichannel coordination of departments and working teams to enhance communication (Chaffey \& Allen, 2015), decision-making processes and timely customer information. It also requires the development of e-marketing and digital capabilities (Alford \& Page, 2015) to build more user-centered business models and foster innovative and agile marketing practices (McGowan \& Durkin, 2002). Moreover, lean and agile practices in manufacturing realm, to avoid waste and unnecessary production steps (Potdar et al., 2017), have been recently exported to marketing domain (Chaffey \& Allen, 2015; Hoogveld \& Koster, 2016b) to ensure systematic and continuous improvements in order to reduce waste and inefficiency, speed up production cycles and enhance expertise of people (Womack \& Jones, 2010). Following the methodology of Webster \& Watson (2002), we perform detailed concept matrices to understand how ITCs and DMCs interact, and identify the theoretical underpinnings for an Agile Marketing Capability. Inspired by the work of Barrales-Molina et al. (2014), the theoretical concepts are synthesized in terms of: features or key characteristics that distinguish a capability from the others; functions or role played by the capability and the expected effect on business; components or underlying processes under which the capability is developed; types or different typologies or ways through which the capability may display (see Table 1 and 2).

\section{THEORETICAL UNDERPINNINGS OF DYNAMIC MARKETING CAPABILITIES AND IT CAPABILITIES}

\section{Dynamic marketing capabilities literature review}

DMCs account for how dynamic capabilities (Eisenhardt \& Martin, 2000; Teece, Pisano, \& Shuen, 1997) or "firm's ability to integrate, build, and reconfigure internal and external competences to address rapidly changing environments” (Teece et al., 1997; p. 516), have evolved into more cross-functional marketing capabilities (Barrales-Molina et al., 2014) to better "sense and seize, or respond to, new opportunities” (Orlandi, 2016; p. 2), and cope with high competitiveness (Ceric, 2016; Takata, 2016). 
Table 1. Concept matrix of Dynamic Marketing Capabilities underpinnings.

\begin{tabular}{|c|c|c|c|c|c|c|c|c|c|c|c|c|}
\hline \multirow{3}{*}{$\begin{array}{l}\text { Determinants } \\
\text { Articles } \\
\text { (Barrales-Molina } \\
\text { et al., 2014) }\end{array}$} & \multicolumn{2}{|c|}{ Features } & \multicolumn{3}{|c|}{ Functions } & \multicolumn{3}{|c|}{ Components } & \multicolumn{4}{|c|}{ Types } \\
\hline & 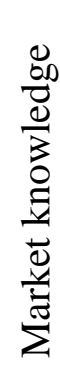 & 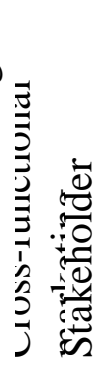 & & 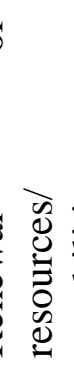 & 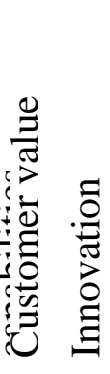 & 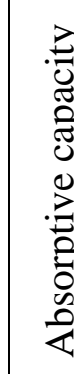 & 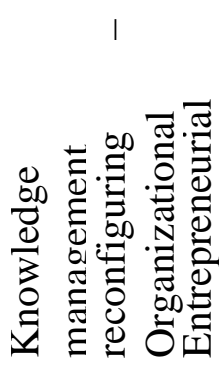 & 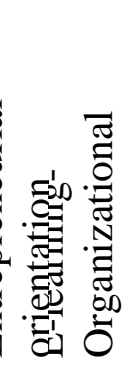 & 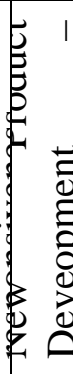 & 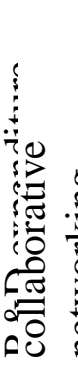 & 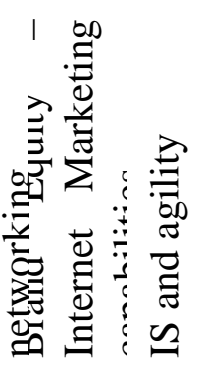 & 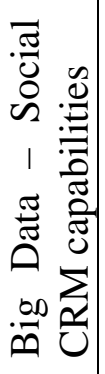 \\
\hline & $\mathrm{X}$ & $\mathbf{X}$ & & $\mathbf{X}$ & $I$ & $\mathbf{X}$ & $\mathbf{X}$ & & $\mathbf{X}$ & $\mathbf{X}$ & & \\
\hline $\begin{array}{l}\text { (Brodie, Benson- } \\
\text { Rea, \& Medlin, } \\
\text { 2016) }\end{array}$ & 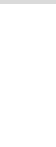 & & & & & & & & & & $\mathbf{X}$ & \\
\hline $\begin{array}{l}\text { (Bruni \& Verona, } \\
\text { 2009) }\end{array}$ & & $\mathbf{X}$ & & & & & & & $\mathbf{X}$ & $\mathbf{X}$ & & \\
\hline $\begin{array}{l}\text { (Cacciolatti } \quad \& \\
\text { Lee, 2016) }\end{array}$ & & & & & & & & & & $\mathbf{X}$ & & \\
\hline $\begin{array}{l}\text { (Ciunova- } \\
\text { Shuleska, Osakwe, } \\
\text { \& Palamidovska- } \\
\text { Sterjadovska, } \\
\text { 2016) }\end{array}$ & & & & & & & & & & & $\mathbf{X}$ & \\
\hline $\begin{array}{l}\text { (Costello \& } \\
\text { McNaughton, } \\
\text { 2016) }\end{array}$ & & & & & & & & $\mathbf{X}$ & & & & \\
\hline $\begin{array}{l}\text { (Eng \& Okten, } \\
\text { 2011) }\end{array}$ & & & & & $\mathbf{X}$ & & & & & $\mathrm{X}$ & & \\
\hline $\begin{array}{l}\text { Evers, } \\
\text { and } \\
\text { (2012) }\end{array}$ & & $\mathbf{X}$ & & $\mathbf{X}$ & & & & & & $\mathbf{X}$ & $\mathbf{X}$ & \\
\hline $\begin{array}{l}\text { (Heirati \& O’Cass, } \\
\text { 2016) }\end{array}$ & & & & & & & & & & $\mathbf{X}$ & & \\
\hline $\begin{array}{l}\text { (Mathews, } \\
\text { Bianchi, Perks, } \\
\text { Healy, \& } \\
\text { Wickramasekera, } \\
\text { 2016) }\end{array}$ & & & & & & & & & & & $\mathbf{X}$ & $\mathbf{X}$ \\
\hline $\begin{array}{l}\text { (Jeng } \\
2016)\end{array} \quad \& \quad$ Pak, & & & & & $\mathbf{X}$ & & & & & & & \\
\hline $\begin{array}{l}\text { (Johnson, Friend, } \\
\text { \& Lee, 2017) }\end{array}$ & & $X$ & & & $X$ & & $X$ & & & & & $\mathrm{X}$ \\
\hline $\begin{array}{l}\text { (Kazadi, Lievens, } \\
\text { \& Mahr, 2016) }\end{array}$ & & $\mathbf{X}$ & & & & & & & & & & \\
\hline $\begin{array}{l}\text { (Konwar et al., } \\
\text { 2017) }\end{array}$ & & $\mathbf{X}$ & & & $x$ & & $\mathbf{X}$ & & & & & \\
\hline $\begin{array}{l}\text { (Lisboa, } \\
\text { Skarmeas, \& }\end{array}$ & & & & & & & $\mathrm{X}$ & & & & & \\
\hline
\end{tabular}




\begin{tabular}{|c|c|c|c|c|c|c|c|c|}
\hline Saridakis, 2016) & & & & & & & & \\
\hline $\begin{array}{l}\text { (Martin \& Javalgi, } \\
\text { 2016) }\end{array}$ & & & & $\mathbf{X}$ & & & & \\
\hline $\begin{array}{l}\text { (Merrilees, } \\
\text { Rundle-Thiele, \& } \\
\text { Lye, 2011) }\end{array}$ & & & & & & $\mathbf{X}$ & & \\
\hline $\begin{array}{l}\text { (Mikalef \& Pateli, } \\
\text { 2017) }\end{array}$ & & & $\mathbf{X}$ & & & & & \\
\hline (Morgan, 2012) & $\mathbf{X}$ & $\mathbf{X}$ & & & & $\mathbf{X}$ & & \\
\hline $\begin{array}{l}\text { (Najafi-Tavani, } \\
\text { Sharifi, \& Najafi- } \\
\text { Tavani, 2016) }\end{array}$ & & & $\mathbf{X}$ & & & $\mathbf{X}$ & & \\
\hline (Orlandi, 2016) & & & & $\mathbf{X}$ & & & & \\
\hline $\begin{array}{l}\text { (Raymond, } \\
\text { Bergeron, } \\
\text { Croteau, \& St- } \\
\text { Pierre, 2015) }\end{array}$ & & & $\mathbf{X}$ & & & & & \\
\hline $\begin{array}{l}\text { (Sharma, Davcik, } \\
\text { \& Pillai, 2016) }\end{array}$ & $X$ & & & & $\mathbf{X}$ & $\mathbf{X}$ & $\mathbf{X}$ & \\
\hline (Takata, 2016) & & & & & & $\mathbf{X}$ & & \\
\hline $\begin{array}{l}\text { (Tarafdar \& } \\
\text { Qrunfleh, 2017) }\end{array}$ & & & & & & & & $\mathbf{X}$ \\
\hline $\begin{array}{l}\text { (Trainor, } \\
\text { Andzulis, Rapp, \& } \\
\text { Agnihotri, 2014) }\end{array}$ & & & & & & & & $\mathbf{X}$ \\
\hline (Tsai, 2015) & & $\mathbf{X}$ & & & & $\mathbf{X}$ & $\mathbf{X}$ & $\mathbf{X}$ \\
\hline $\begin{array}{l}\text { (Wang \& Kim, } \\
\text { 2017) }\end{array}$ & & $\lambda$ & & & & & & $\mathbf{X}$ \\
\hline $\begin{array}{l}\text { (Wang \& } \\
\text { Sengupta, 2016) }\end{array}$ & $\mathbf{X}$ & & & & $\mathbf{X}$ & & $\mathbf{X}$ & \\
\hline $\begin{array}{l}\text { (Wang, Hu, \& Hu, } \\
\text { 2013) }\end{array}$ & & $\lambda$ & & & & $\mathbf{X}$ & & $\mathbf{X}$ \\
\hline $\begin{array}{l}\text { (Wilden \& } \\
\text { Gudergan, 2015) }\end{array}$ & & & $\mathbf{X}$ & & & & & \\
\hline $\begin{array}{l}\text { (Zhang, Jiang, } \\
\text { Shabbir, \& Du, } \\
\text { 2015) }\end{array}$ & & & & & & & $\mathbf{X}$ & \\
\hline
\end{tabular}

Source: own elaboration

As features, scholars point out: market knowledge or insights to implement new organizational processes (Konwar et al., 2017; Morgan, 2012), strategies and innovation initiatives (Bruni \& Verona, 2009); cross-functional marketing, or internal and external involvement of transversal departments/roles (Bruni \& Verona, 2009; Johnson et al., 2017; E. T. Wang et al., 2013); stakeholders portfolio, as key root of knowledge for innovation (Kazadi et al., 2016) and learning processes (Evers et al., 2012); capability enhancement or higher skills and expertise by steadily reconfiguring firm's resources (Morgan, 2012).

About components, literature emphasizes: absorptive capacity process of DMCs development (Najafi-Tavani et al., 2016) by exploiting external knowledge (Raymond 
et al., 2015); knowledge management mechanism to convert knowledge into organizational routines (Konwar et al., 2017); sensing and reconfiguring processes of market patterns (Wilden \& Gudergan, 2015) to foster firm's organizational agility (Mikalef \& Pateli, 2017) in the management of market changes and growth opportunities (Lu et al., 2011); entrepreneurial orientation mechanism towards innovativeness, risk taking and proactiveness (Lisboa et al., 2016) to enhance performance and competitiveness (Martin \& Javalgi, 2016); e-learning processes (Costello \& McNaughton, 2016) through web-based applications to speed up learning mechanisms for superior DMCs, and to enhance organizational responsiveness (Orlandi, 2016) in acquiring knowledge and technologies, and responding to environmental changes.

Key functions played by DMCs, may be synthesized as: renewal of resources and capabilities to adapt internal/external resources and fit market requirements (Morgan, 2012); higher customer value by managing data, technology, customer knowledge and relationships across firm's network (Konwar et al., 2017); innovation (Johnson et al., 2017) to achieve positive outcomes, competitive advantage and profitability (Jeng \& Pak, 2016).

Across literature, there are multiple ways or types through which DMCs may display, for instance: new product development (Barrales-Molina et al., 2014; Evers et al., 2012; Sharma et al., 2016; H.-M. D. Wang \& Sengupta, 2016) and R\&D expenditure (Sharma et al., 2016; Wang \& Sengupta, 2016); market orientation (MO) or collaborative networking capabilities (Najafi-Tavani et al., 2016; Tsai, 2015); brand equity (Tsai, 2015) or internet marketing capabilities (Mathews et al., 2016); Information Systems (IS) capability for agility (Tarafdar \& Qrunfleh, 2017; Tsai, 2015); big data (Johnson et al., 2017) or social CRM capabilities (Trainor et al., 2014; Z. Wang \& Kim, 2017). (see Table 1).

\section{IT capabilities literature review}

According to the resource-based view (Wade \& Hulland, 2004), ITCs are competitive resources to develop higher-quality IT products and services, achieve superior performance and market value (Saunders \& Brynjolfsson, 2016), and improve decision-making process through information flows (Campos, 2016). As a combination of multiple elements like internal and external human resources, software applications, etc. (Debreceny \& Gray, 2013), they enable firms to be more agile in aligning strategies and information systems in order to promptly reconfigure resources and capabilities.

Table 2.Concept matrix of IT Capabilities underpinnings. 


\begin{tabular}{|c|c|c|c|c|c|c|c|c|c|}
\hline & Feat & ures & Components & Func & tions & & Type & & \\
\hline Articles & 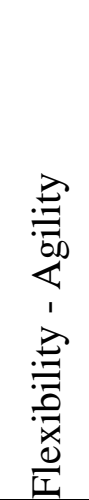 & 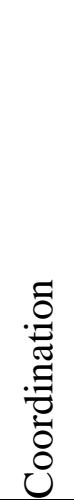 & 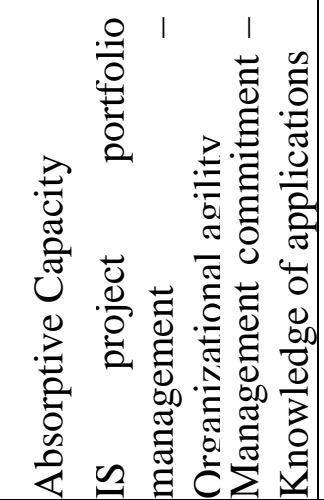 & 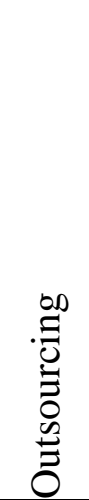 & $\begin{array}{l}.0 \\
.0 \\
0 \\
0 \\
0 \\
0\end{array}$ & 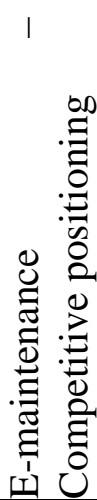 & 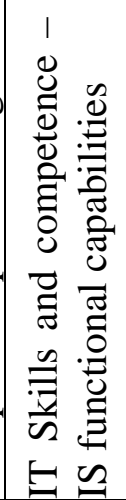 & 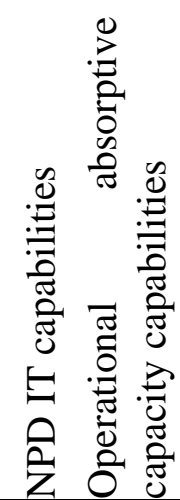 & 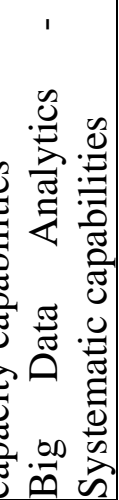 \\
\hline $\begin{array}{l}\text { (Addas \& } \\
\text { Pinsonneault, 2016) }\end{array}$ & & & & & & & & $\mathbf{X}$ & \\
\hline $\begin{array}{l}\text { (Ainin, Akma Mohd } \\
\text { Salleh, Bahri, \& } \\
\text { Mohd Faziharudean, } \\
\text { 2015) }\end{array}$ & & & & & & & $X$ & & $X$ \\
\hline (Aral \& Weill, 2007) & & & & & & & $\mathbf{X}$ & & \\
\hline $\begin{array}{l}\text { (Arnold, Benford, } \\
\text { Canada, \& Sutton, } \\
\text { 2015) }\end{array}$ & & & & & & & & & \\
\hline $\begin{array}{l}\text { (Bendoly, } \\
\text { Bharadwaj, } \quad \& \\
\text { Bharadwaj, 2012) }\end{array}$ & & $\mathbf{X}$ & & & & & & $\mathbf{X}$ & \\
\hline $\begin{array}{l}\text { (Bharadwaj, } \\
\text { Bharadwaj, } \\
\text { Bendoly, 2007) }\end{array}$ & & $\mathbf{X}$ & & & & & & & \\
\hline $\begin{array}{l}\text { (G. D. Bhatt, Grover, } \\
\text { \& GROVER, 2005) }\end{array}$ & $\mathbf{X}$ & & & & & & $\mathbf{X}$ & & \\
\hline $\begin{array}{l}\text { (G. Bhatt, Emdad, } \\
\text { Roberts, \& Grover, } \\
2010)\end{array}$ & $\mathbf{X}$ & & & & & & & & \\
\hline (Campos, 2016) & & & & & & $\mathbf{X}$ & & & \\
\hline $\begin{array}{l}\text { (Cao, Duan, Cadden, } \\
\text { \& Minocha, 2016) }\end{array}$ & & & & & & & & & $\mathbf{X}$ \\
\hline $\begin{array}{l}\text { (Cepeda-Carrion, } \\
\text { Cegarra-Navarro, \& } \\
\text { Jimenez-Jimenez, } \\
\text { 2012) }\end{array}$ & & & $\mathrm{X}$ & & & & & & \\
\hline $\begin{array}{l}\text { (Cepeda-Carrión, } \\
\text { Gabriel Cegarra- } \\
\text { Navarro, \& Leal- } \\
\text { Millán, 2012) }\end{array}$ & & & $X$ & & $\mathbf{X}$ & & & & \\
\hline (Ceric, 2016) & & & & & & & & & $\mathbf{X}$ \\
\hline
\end{tabular}




\begin{tabular}{|c|c|c|c|c|c|}
\hline $\begin{array}{l}\text { (Cheng, Wong, \& } \\
\text { Motwani, 2009) }\end{array}$ & & & & $\mathbf{X}$ & \\
\hline $\begin{array}{l}\text { (Chen, Wang, Nevo, } \\
\text { Benitez-Amado, \& } \\
\text { Kou, 2015) }\end{array}$ & & & & $\mathbf{X}$ & \\
\hline $\begin{array}{l}\text { (Chen, Wang, Nevo, } \\
\text { Benitez, \& Kou, } \\
\text { 2017) }\end{array}$ & $\mathbf{X}$ & & & & \\
\hline $\begin{array}{l}\text { (Cui, Ye, Teo, \& Li, } \\
\text { 2015) }\end{array}$ & $\mathbf{X}$ & $\mathrm{X}$ & & $\mathbf{X}$ & \\
\hline $\begin{array}{l}\text { (Dai, Kauffman, \& } \\
\text { March, 2007) }\end{array}$ & $\mathbf{X}$ & & & & \\
\hline $\begin{array}{l}\text { (Daniel, Ward, \& } \\
\text { Franken, 2014) }\end{array}$ & $\mathbf{X}$ & & $\mathrm{X}$ & & \\
\hline $\begin{array}{l}\text { (Devece, Palacios- } \\
\text { Marqués, Galindo- } \\
\text { Martín, \& } \quad \text { Llopis- } \\
\text { Albert, 2017) }\end{array}$ & & & & $\mathbf{X}$ & \\
\hline $\begin{array}{l}\text { (Doherty \& Terry, } \\
\text { 2009) }\end{array}$ & & & & $\mathbf{X}$ & \\
\hline $\begin{array}{l}\text { (Engelbrecht, } \\
\text { Johnston, \& Hooper, } \\
\text { 2017) }\end{array}$ & & & $\mathrm{X}$ & & \\
\hline $\begin{array}{l}\text { (Felipe, Roldán, \& } \\
\text { Leal-Rodríguez, } \\
\text { 2016) }\end{array}$ & & & $\mathrm{X}$ & & \\
\hline $\begin{array}{l}\text { (Fernhaber \& Patel, } \\
\text { 2012) }\end{array}$ & & $\mathrm{X}$ & & & \\
\hline $\begin{array}{l}\text { (Gupta \& George, } \\
\text { 2016) }\end{array}$ & & & & & $\mathbf{X}$ \\
\hline $\begin{array}{l}\text { (H.-S. Han, Lee, \& } \\
\text { Seo, 2008) }\end{array}$ & & & & $\mathbf{X}$ & \\
\hline $\begin{array}{l}\text { (K. Han, Kauffman, } \\
\text { \& Nault, 2011) }\end{array}$ & & $\mathrm{X}$ & & $\mathbf{X}$ & \\
\hline $\begin{array}{l}\text { (Hernández-Perlines, } \\
\text { Moreno-García, \& } \\
\text { Yáñez-Araque, } \\
\text { 2016) }\end{array}$ & & $X$ & & & \\
\hline $\begin{array}{l}\text { (Koo, Lee, Heng, \& } \\
\text { Park, 2017) }\end{array}$ & & & & $\mathbf{X}$ & \\
\hline (Im \& Rai, 2013) & $\mathbf{X}$ & & & & \\
\hline (Iyer, 2011) & $\mathbf{X}$ & & & & \\
\hline $\begin{array}{l}\text { (Lee, Sambamurthy, } \\
\text { Lim, \& Wei, 2015) }\end{array}$ & X & & & & \\
\hline (Lu et al., 2011) & $\mathbf{X}$ & & & $\mathbf{X}$ & \\
\hline $\begin{array}{ll}\text { (Bryan Jean, } \\
\text { Sinkovics, \& Kim, } \\
\text { 2008) }\end{array}$ & & $X$ & & & \\
\hline $\begin{array}{l}\text { (Mauerhoefer, } \\
\text { Strese, \& Brettel, }\end{array}$ & & & & & $\mathbf{X}$ \\
\hline
\end{tabular}




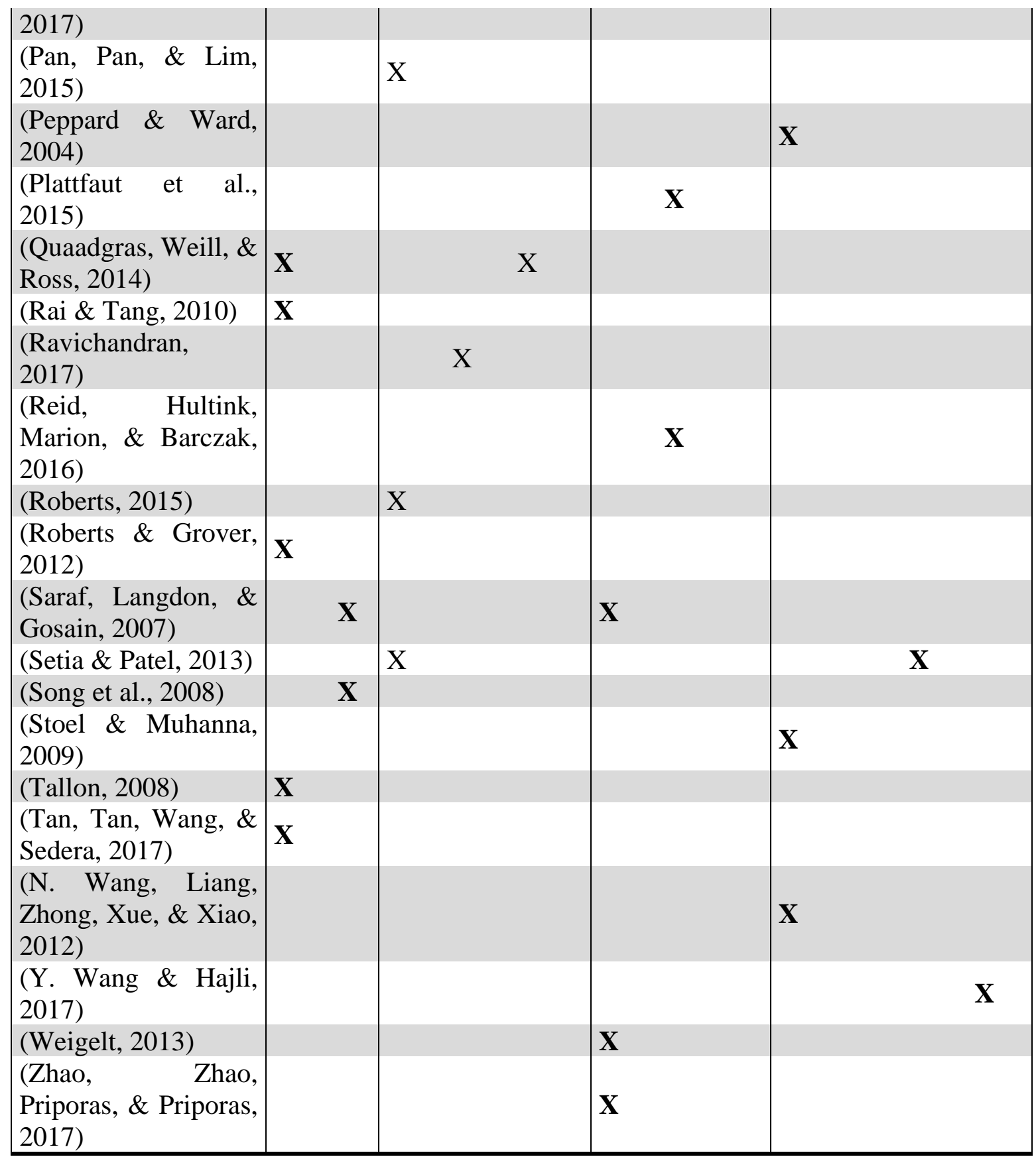

Source: own elaboration

As features, scholars identify: flexibility and agility or IT applications adaptability to environmental changes to ensure speed up in decision making and proactiveness to quickly respond to market trends (Quaadgras et al., 2014; Roberts \& Grover, 2012); coordination to foster information sharing across different functions/departments (Bendoly et al., 2012; Bhatt et al., 2005), the specialization of competencies (Bharadwaj et al., 2007), synergies for interfirm relationships, knowledge sharing, operational routines etc. (Im \& Rai, 2013; Saraf et al., 2007).

As components, scholars highlight: absorptive capacity process to monitor market trends and quickly exploit external knowledge (Cepeda-Carrion et al., 2012; CepedaCarrión et al., 2012; Pan et al., 2015; Setia \& Patel, 2013) to improve offerings; IS project portfolio management to "reconfigure their resources and capabilities to 
match changing market and economic conditions” (Daniel et al., 2014; p. 95) and to enhance organizational agility in capturing new business opportunities (Felipe et al., 2016); management commitment process to develop ITCs "as an explicit, specific, high-level agreement within an organization to operate in a given way" (Quaadgras et al., 2014; p. 115), by leveraging on specific knowledge of applications (Engelbrecht et al., 2017), that is, the way in which applications are developed within an organization.

ITCs functions may be synthesized as: outsourcing relationships (Han et al., 2008), to improve inter-firm relationships, reduce costs, access to skilled people etc. (Cheng et al., 2009; Zhao et al., 2017; Saraf et al., 2007) and achieve superior market knowledge and value (Han et al., 2011); innovation, since they facilitate the development of NPD projects particularly in turbulent environments, where it is necessary to be flexible in responding to market changes, and adapting to new market requirements (Devece et al., 2017; Lu et al., 2011); e-maintenance (Campos, 2016), which concerns the usage of technologies for organizational purposes, to improve firm's competitive positioning (Doherty \& Terry, 2009) in the marketplace.

Scholars stress the presence of many types of ITCs, such as: IT skills and competencies on IT field (Bhatt \& Grover, 2005) as IS functional capabilities (Ainin et al., 2015); New Product Development IT capabilities (Addas \& Pinsonneault, 2016; Mauerhoefer et al., 2017); operational absorptive capacity capabilities (Setia and Patel, 2013); big data analytics capabilities (Gupta and George, 2016) or systematic capabilities (Cao et al., 2016).

\section{TOWARDS AN AGILE MARKETING CAPABILITY: A FRAMEWORK AND PROPOSITIONS}

Working from the literature review presented above, we develop a theoretical model (figure 1), explaining the main dimensions for an Agile Marketing Capability in terms of features, functions, components and types. The model includes a series of propositions that explain the conditions under which the agile marketing capability could be developed.

\section{Features}

Flexibility or agility corresponds to firms' ability to promptly react to market changes (Tallon, 2008). In doing so, firms improve market knowledge and information concerning their stakeholder portfolio (Evers et al., 2012) to perform proper business adjustments ( $\mathrm{Lu}$ et al., 2011). The combination between flexibility or agility with market knowledge and stakeholder portfolio, determines the first feature of the agile marketing capabilities: the agile market management feature.

P1a: Agile market management will be affected by the combination of flexibility (or agility) with market knowledge and stakeholder portfolio.

$P 1 b$ : The greater the levels of agile market management, the greater the level of agile marketing capabilities.

Internal and external coordination (Bhatt \& Grover, 2005; Song et al., 2008), together with the development of cross-functional marketing capabilities among transversal departments and working teams (Bruni \& Verona, 2009; Wang et al., 2013), foster 
ongoing capability enhancement through learning and competitive benchmarks (Morgan, 2012). The combination between coordination with cross-functional marketing and capability enhancement, determines the second feature of agile marketing capabilities: the cross-functional coordination feature.

P1c: Cross-functional coordination will be affected by the combination of coordination with cross-functional marketing and capability enhancement

P1d: The greater the levels of cross-functional coordination, the greater the level of agile marketing capabilities.

\section{Functions}

Outsourcing enables to exploit external resources for superior performance and customer value (Han et al., 2011) and to carry out cross-functional processes for the ongoing renewal of resources and market expectations' fitting (Konwar et al., 2017). The combination between outsourcing with renewal of resources/capabilities and customer value, determines the first function of agile marketing capabilities: the outsourcing for higher customer value function.

P2a: Outsourcing for higher customer value will be affected by the combination of out-sourcing with renewal of resources/capabilities and customer value

$P 2 b$ : The greater the levels of outsourcing for higher customer value, the greater the level of agile marketing capabilities;

Innovation activity for new products and services to fit new market conditions (Lu et al., 2011), driven by the use of IT tools for marketing (Alford \& Page, 2015), fosters firms' competitive positioning (Doherty \& Terry, 2009) and e-maintenance (Campos, 2016), that is, the exploitation of technology to perform more efficient collaboration, cooperation and learning processes. The combination between innovation and emaintenance-competitive positioning, determines the second function of agile marketing capabilities: the ongoing innovation for competitiveness function.

P2c: Ongoing innovation for competitiveness will be affected by the combination of innovation and e-maintenance-competitive positioning

P2d: The greater the levels of ongoing innovation for competitiveness, the greater the level of agile marketing capabilities.

\section{Components}

Absorptive capacity of market knowledge and its management (Barrales-Molina et al., 2014) lowers waste and unnecessary steps, and foster marketing alignment with changing scenarios. In doing so, firms enhance organizational agility (Mikalef \& Pateli, 2017) and even sensing and reconfiguring processes (Wilden \& Gudergan, 2015) for managing their IS project portfolio according to environment (Daniel et al., 2014). The combination between absorptive capacity and knowledge management together with sensing and reconfiguring-organizational agility and IS project portfolio management-organizational agility, determines the first component of agile marketing capabilities: the absorptive organizational agility component.

P3a: Absorptive organizational agility will be affected by the combination of absorptive capacity and knowledge management together with sensing and reconfiguring-organizational agility and IS project portfolio managementorganizational agility 
$P 3 b$ : The greater the levels of absorptive organizational agility, the greater the level of agile marketing capabilities.

The processes of knowledge of applications (Engelbrecht et al., 2017), and management commitment for ITCs (Quaadgras et al., 2014) affects learning mechanisms through IT tools and even firms' entrepreneurial orientation in managing marketing activities (Lisboa et al., 2016; Martin \& Javalgi, 2016). and organizational responsiveness (Orlandi, 2016) in capturing environmental changes. The combination between knowledge of applications-management commitment with entrepreneurial orientation and e-learning-organizational responsiveness, determines the second component of agile marketing capabilities: the e-responsive management orientation component.

P3c: E-responsive management orientation will be affected by the combination of knowledge of applications-management commitment with entrepreneurial orientation and e-learning-organizational responsiveness

P3d: The greater the levels of e-responsive management orientation, the greater the level of agile marketing capabilities.

\section{Types}

R\&D competencies foster innovation (Sharma et al., 2016), and continuous improvements of routines and processes through digital tools, that is, new product development capabilities (Bendoly et al., 2012). The combination between NPDR\&D expenditure and NPD IT capabilities, determines the first type of agile marketing capabilities: the IT-driven continuous improvements capabilities.

P4a: IT-driven continuous improvements capabilities will be affected by the combination of NPD-R\&D expenditure and NPD IT capabilities

$P 4 b$ : The greater levels of IT-driven continuous improvements capabilities, the greater the level of agile marketing capabilities

Big data-Social CRM capabilities facilitate the collection of multiple data towards firm's business environment (Johnson et al., 2017) generated from customer interactions through IT tools (Trainor et al., 2014), and foster market orientationcollaborative networking capabilities to exploit this knowledge and meet market requirements (Setia \& Patel, 2013). The combination between big data-social CRM capabilities with big data analytics-systematic capabilities and MO or collaborative networking capabilities, determines the second type of agile marketing capabilities: the systematic market-oriented big data capabilities.

P4c: Systematic market-oriented big data capabilities will be affected by the combination of big data-social CRM capabilities with big data analytics-systematic capabilities and MO or collaborative networking capabilities

P4d: The greater the levels of systematic market-oriented big data capabilities, the greater level of agile marketing capabilities

Marketing trends require firms to develop proper IT skills and competencies, and also internet marketing capabilities to be proactive towards the marketplace (Wang et al., 2012) and better perform marketing activities like sales, market research etc. (Mathews et al., 2016). In doing so, they improve their brand equity (Brodie et al., 
2016) and competitive advantage (Barney, 2014) through the employment of higher capabilities relative to competitors (Tsai, 2015). The combination between IT skills and competencies with brand equity-internet marketing capabilities, determines the third type of agile marketing capabilities: the e-marketing for brand capabilities.

P4e: E-marketing for brand capabilities will be affected by the combination of IT skills and competencies with brand equity-internet marketing capabilities

P4f: The greater the levels of e-marketing for brand capabilities, the greater the level of ag-ile marketing capabilities.

Operational absorptive capacity capabilities facilitate the fitting of market requirements (Setia \& Patel, 2013), and strongly relates to Information Systems (IS) capability for agility (Tarafdar \& Qrunfleh, 2017) through which they implement dynamic and continuous interactions to capture future scenarios of markets' needs (Tsai, 2015). The combination between operational absorptive capacity capabilities with IS agility, determine the fourth type of agile marketing capabilities: the IS agility-to-market capabilities.

P4g: IS agility-to-market capabilities will be affected by the combination of operational absorptive capacity capabilities with IS agility

$P 4 h$ : The greater the levels of IS agility-to-market capabilities, the greater the level of agile marketing capabilities.

Drawing on the previous analysis, we define the Agile Marketing Capability as an organizational capability pointed towards outsourcing and continuing innovation activities to achieve superior customer value and competitiveness, by leveraging on agile market management and cross-functional coordination features. It originates from absorptive organizational agility and e-responsive management orientation processes, thanks to which it may display in multiple types of related capabilities, such as IT-driven continuous improvements, systematic market-oriented big data, emarketing for brand, and IS agility-to-market (see Figure 1). 


\section{Global Marketing Conference at Tokyo Proceedings}

Figure 1. Framework of the Agile Marketing Capability.

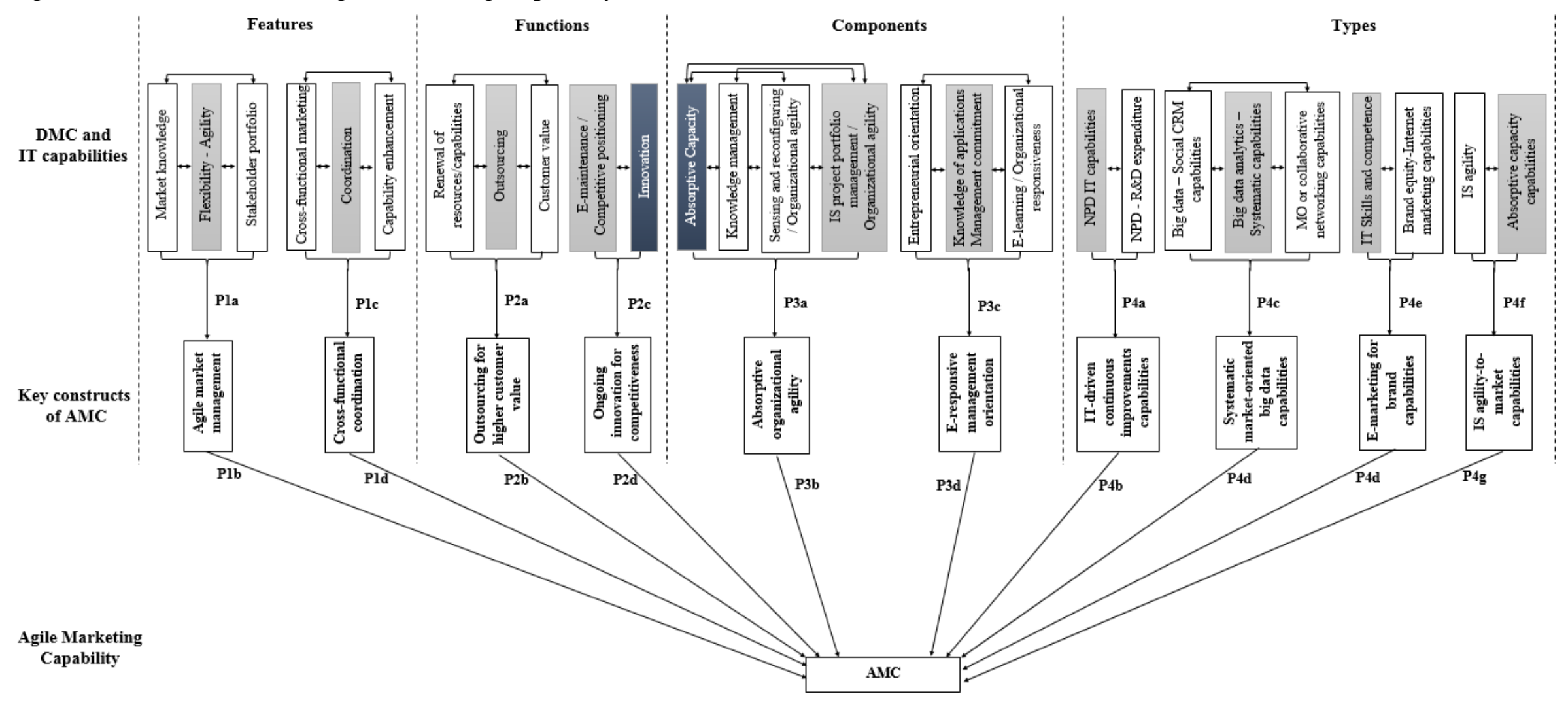

Source: own elaboration 


\section{DISCUSSIONS AND CONCLUSIONS}

Agile concept has recently shifted from software development and manufacturing fields (Gren et al., 2015) towards Agile Marketing realm (Accardi-Petersen, 2011; van den Driest \& Weed, 2014), since differently from traditional marketing approaches, agile features allow to cope with changing scenarios, and to overcome practical issues as long product development cycles, wasted time and resources etc., and provide responses in an iterative and incremental manner, putting customer and market feedbacks at the centre (Ewel, 2013). Nevertheless, despite the importance of this topic in current contexts of turbulence, dynamism and high competitive rivalry, prior literature lacks of defining and deepening proper capabilities of Agile Marketing. By combining DMCs and ITCs theories, our study extends previous literature by identifying the main constructs of Agile Marketing approach, and develops key propositions for an Agile Marketing Capability development. Specifically, while prior research emphasized how DMCs employment fosters adaptability to dynamic contexts and how IT capabilities serve to achieve these aims (Barrales-Molina et al., 2014; Song et al., 2008), our study details the specific marketing mechanisms which generate the theoretical bedrocks of this specific capability. Future studies could further deepen new trends in marketing capabilities' domain, and even other types of capabilities which extend Agile Marketing understanding. Furthermore, while prior research emphasized the growing importance of agile theory in marketing domain (Gren et al., 2015; Hoogveld \& Koster, 2016a, 2016b), our study explores the key dimensions (features, components, functions and types) under which an Agile Marketing Capability could be developed, that future research could further examine, as well as test the propositions developed. Finally, this study provides a first definition of the Agile Marketing Capability, which could be additionally extended by future researchers towards this field of studies.

\section{REFERENCES}

Accardi-Petersen, M. (2011). How to Get Moving in Agile . In Agile Marketing (pp. 171-187). Springer.

Addas, S., \& Pinsonneault, A. (2016). IT capabilities and NPD performance: examining the mediating role of team knowledge processes. Knowledge Management Research \& Practice, 14(1), 76-95.

Ainin, S., Akma Mohd Salleh, N., Bahri, S., \& Mohd Faziharudean, T. (2015). Organization's Performance, Customer Value and the Functional Capabilities of Information Systems. Information Systems Management, 32(1), 2-14.

Alford, P., \& Page, S. J. (2015). Marketing technology for adoption by small business. The Service Industries Journal, 35(11-12), 655-669.

Aral, S., \& Weill, P. (2007). IT assets, organizational capabilities, and firm performance: How resource allocations and organizational differences explain performance variation. Organization Science, 18(5), 763-780.

Arnold, V., Benford, T., Canada, J., \& Sutton, S. G. (2015). Leveraging integrated information systems to enhance stra-tegic flexibility and performance: The enabling role of enterprise risk management. International Journal of Accounting Information Systems, 19, 1-16.

Barrales-Molina, V., Martínez-López, F. J., \& Gázquez-Abad, J. C. (2014). Dynamic marketing capabilities: Toward an integrative framework. International Journal of Management Reviews, 16(4), 397-416. 
Bendoly, E., Bharadwaj, A., \& Bharadwaj, S. (2012). Complementary Drivers of New Product Development Perfor-mance: Cross-Functional Coordination, Information System Capability, and Intelligence Quality. Production and Operations Management, 21(4), 653-667.

Bharadwaj, S., Bharadwaj, A., \& Bendoly, E. (2007). The performance effects of complementarities between infor-mation systems, marketing, manufacturing, and supply chain processes. Information Systems Research, 18(4), 437-453.

Bhatt, G. D., Grover, V., \& GROVER, V. (2005). Types of information technology capabilities and their role in com-petitive advantage: An empirical study. Journal of Management Information Systems, 22(2), 253-277.

Bhatt, G., Emdad, A., Roberts, N., \& Grover, V. (2010). Building and leveraging information in dynamic environments: The role of IT infrastructure flexibility as enabler of organizational responsiveness and competitive advantage. Information \& Management, 47(7), 341-349.

Brodie, R. J., Benson-Rea, M., \& Medlin, C. J. (2016). Branding as a dynamic capability: Strategic advantage from integrating meanings with identification. Marketing Theory, 1470593116679871.

Bruni, D. S., \& Verona, G. (2009). Dynamic marketing capabilities in Science-based firms: An exploratory investigation of the pharmaceutical industry. British Journal of Management, 20(s1), S101-S117.

Bryan Jean, R.-J., Sinkovics, R. R., \& Kim, D. (2008). Information technology and organizational performance within international business to business relationships: a review and an integrated conceptual framework. International Marketing Review, 25(5), 563-583.

Cacciolatti, L., \& Lee, S. H. (2016). Revisiting the relationship between marketing capabilities and firm performance: The moderating role of market orientation, marketing strategy and organisational power.

Campos, J. (2016). Managing the information systems in the industrial domain. Cogent Business \& Management, 3(1).

Cao, G., Duan, Y., Cadden, T., \& Minocha, S. (2016). Systemic capabilities: the source of IT business value. Infor-mation Technology \& People, 29(3), 556-579.

Cepeda-Carrion, G., Cegarra-Navarro, J. G., \& Jimenez-Jimenez, D. (2012). The effect of absorptive capacity on inno-vativeness: Context and information systems capability as catalysts. British Journal of Management, 23(1), 110-129.

Cepeda-Carrión, G., Gabriel Cegarra-Navarro, J., \& Leal-Millán, A. G. (2012). Finding the hospital-in-the-home units' innovativeness. Management Decision, 50(9), 1596-1617.

Ceric, A. (2016). Analysis of interactions between IT and organisational resources in a manufacturing organisation using cross-impact analysis. Journal of Enterprise Information Management, 29(4), 589-611.

Chaffey, D., \& Allen, R. (2015). Managing Digital Marketing in 2015. Smart Insights. Recuperado de http://www. smartinsights. com/guides/managingdigitalmarketing-2015.

Chen, Y., Wang, Y., Nevo, S., Benitez, J., \& Kou, G. (2017). Improving strategic flexibility with information technologies: insights for firm performance in an emerging economy. Journal of Information Technology, 32(1), 10-25.

Chen, Y., Wang, Y., Nevo, S., Benitez-Amado, J., \& Kou, G. (2015). IT capabilities and product innovation perfor-mance: The roles of corporate entrepreneurship and competitive intensity. Information \& Management, 52(6), 643-657. 
Cheng, C.-H., Wong, K.-F., \& Motwani, J. (2009). Information systems outsourcing activities in China: the experience of Hong Kong small and medium enterprises. International Journal of Procurement Management, 2(2), 105-124.

Ciunova-Shuleska, A., Osakwe, C. N., \& Palamidovska-Sterjadovska, N. (2016). Complementary impact of capabilities and brand orientation on SMBs performance. Journal of Business Economics and Management, 17(6), 12701285.

Costello, J. T., \& McNaughton, R. B. (2016). Can Dynamic Capabilities be Developed Using Workplace E-learning Processes? Knowledge and Process Management, 23(1), 73-87.

Cui, T., Ye, H. J., Teo, H. H., \& Li, J. (2015). Information technology and open innovation: A strategic alignment per-spective. Information \& Management, 52(3), 348-358.

Dai, Q., Kauffman, R. J., \& March, S. T. (2007). Valuing information technology infrastructures: a growth options ap-proach. Information Technology and Management, 8(1), 1-17.

Daniel, E. M., Ward, J. M., \& Franken, A. (2014). A dynamic capabilities perspective of IS project portfolio manage-ment. The Journal of Strategic Information Systems, 23(2), 95-111.

Debreceny, R. S., \& Gray, G. L. (2013). IT governance and process maturity: A multinational field study. Journal of Information Systems, 27(1), 157-188.

Devece, C., Palacios-Marqués, D., Galindo-Martín, M.-Á., \& Llopis-Albert, C. (2017). Information Systems Strategy and Its Relationship with Innovation Differentiation and Organizational Performance. Information Systems Management.

Doherty, N. F., \& Terry, M. (2009). The role of IS capabilities in delivering sustainable improvements to competitive positioning. The Journal of Strategic Information Systems, 18(2), 100-116.

Drnevich, P. L., \& Croson, D. C. (2013). Information technology and business-level strategy: Toward an integrated theoretical perspective. Mis Quarterly, 37(2).

Eisenhardt, K. M., \& Martin, J. A. (2000). Dynamic capabilities: what are they? Strategic Management Journal, 1105-1121.

Eng, T.-Y., \& Okten, D. (2011). Exploring a dynamic framework of innovative capability: a theoretical integration of technological and marketing capabilities. Technology Analysis \& Strategic Management, 23(9), 1001-1013.

Engelbrecht, J., Johnston, K. A., \& Hooper, V. (2017). The influence of business managers' IT competence on IT pro-ject success. International Journal of Project Management, 35(6), 994-1005.

Evers, N., Andersson, S., \& Hannibal, M. (2012). Stakeholders and marketing capabilities in international new ventures: evidence from Ireland, Sweden and Denmark. Journal of International Marketing, 20(4), 46-71.

Ewel, J. (2013). Getting Started With Agile Marketing.

Felipe, C. M., Roldán, J. L., \& Leal-Rodríguez, A. L. (2016). An explanatory and predictive model for organizational agility. Journal of Business Research, 69(10), 4624-4631.

Fernhaber, S. A., \& Patel, P. C. (2012). How do young firms manage product portfolio complexity? The role of absorp-tive capacity and ambidexterity. Strategic Management Journal, 33(13), 1516-1539. 
Gren, L., Torkar, R., \& Feldt, R. (2015). The prospects of a quantitative measurement of agility: A validation study on an agile maturity model. Journal of Systems and Software, 107, 38-49.

Gupta, M., \& George, J. F. (2016). Toward the development of a big data analytics capability. Information \& Manage-ment, 53(8), 1049-1064.

Han, H.-S., Lee, J.-N., \& Seo, Y.-W. (2008). Analyzing the impact of a firm's capability on outsourcing success: A process perspective. Information \& Management, 45(1), 31-42.

Han, K., Kauffman, R. J., \& Nault, B. R. (2011). Research note-Returns to information technology outsourcing. Information Systems Research, 22(4), 824840.

Heirati, N., \& O’Cass, A. (2016). Supporting new product commercialization through managerial social ties and market knowledge development in an emerging economy. Asia Pacific Journal of Management, 33(2), 411-433.

Hendrix, P. E. (2014). How digital technologies are enabling consumers and transforming the practice of marketing. Journal of Marketing Theory and Practice, 22(2), 149-150.

Hernández-Perlines, F., Moreno-García, J., \& Yáñez-Araque, B. (2016). Training and business performance: the medi-ating role of absorptive capacities. SpringerPlus, 5(1), 2074.

Hoogveld, M., \& Koster, J. (2016a). Measuring the Agility of Omnichannel Operations: an Agile Marketing Maturity Model.

Hoogveld, M., \& Koster, J. M. (2016b). Implementing Omnichannel Strategies The Success Factor of Agile Processes. Advances in Management and Applied Economics, 6(2), 25.

Im, G., \& Rai, A. (2013). IT-enabled coordination for ambidextrous interorganizational relationships. Information Systems Research, 25(1), 72-92.

Iyer, K. N. (2011). Demand chain collaboration and operational performance: role of IT analytic capability and envi-ronmental uncertainty. Journal of Business \& Industrial Marketing, 26(2), 81-91.

Jeng, D. J.-F., \& Pak, A. (2016). The variable effects of dynamic capability by firm size: the interaction of innovation and marketing capabilities in competitive industries. International Entrepreneurship and Management Jour-nal, 12(1), 115-130.

Johnson, J. S., Friend, S. B., \& Lee, H. S. (2017). Big Data Facilitation, Utilization, and Monetization: Exploring the $3 \mathrm{Vs}$ in a New Product Development Process. Journal of Product Innovation Management, 34(5), 640-658.

Kazadi, K., Lievens, A., \& Mahr, D. (2016). Stakeholder co-creation during the innovation process: Identifying capabilities for knowledge creation among multiple stakeholders. Journal of Business Research, 69(2), 525-540.

Konwar, Z., Papageorgiadis, N., Ahammad, M. F., \& McDonald, F. (2017). Dynamic marketing capabilities, foreign ownership modes, sub-national locations and the performance of foreign affiliates in developing economies. International Marketing Review, 34(5), 674-704.

Koo, Y., Lee, J.-N., Heng, C. S., \& Park, J. (2017). Effect of multi-vendor outsourcing on organizational learning: A social relation perspective. Information \& Management, 54(3), 396-413.

Lee, O.-K., Sambamurthy, V., Lim, K. H., \& Wei, K. K. (2015). How does IT ambidexterity impact organizational agility? Information Systems Research, 26(2), 398-417. 
Lisboa, A., Skarmeas, D., \& Saridakis, C. (2016). Entrepreneurial orientation pathways to performance: A fuzzy-set analysis. Journal of Business Research, 69(4), 1319-1324.

Lu, Y., \& Ramamurthy, R. (2011). Understanding the Link Between Information Technology Capability and Organizational Agility: An Empirical Examination Agility: An Empirical Examination. MIS Quarterly, 4, 931-954.

Martin, S. L., \& Javalgi, R. R. G. (2016). Entrepreneurial orientation, marketing capabilities and performance: the moderating role of competitive intensity on Latin American International new ventures. Journal of Business Re-search, 69(6), 2040-2051.

Mathews, S., Bianchi, C., Perks, K. J., Healy, M., \& Wickramasekera, R. (2016). Internet marketing capabilities and international market growth. International Business Review, 25(4), 820-830.

Mauerhoefer, T., Strese, S., \& Brettel, M. (2017). The Impact of Information Technology on New Product Development Performance. Journal of Product Innovation Management.

McGowan, P., \& Durkin, M. G. (2002). Toward an understanding of Internet adoption at the market-ing/entrepreneurship interface. Journal of Marketing Management, 18(3-4), 361-377.

Merrilees, B., Rundle-Thiele, S., \& Lye, A. (2011). Marketing capabilities: Antecedents and implications for B2B SME performance. Industrial Marketing Management, 40(3), 368-375.

Mikalef, P., \& Pateli, A. (2017). Information technology-enabled dynamic capabilities and their indirect effect on competitive performance: Findings from PLS-SEM and fsQCA. Journal of Business Research, 70, 1-16.

Miles, A. (2013). Agile learning: Living with the speed of change. Development and Learning in Organizations: An International Journal, 27(2), 20-22.

Morgan, N. A. (2012). Marketing and business performance. Journal of the Academy of Marketing Science, 40(1), 102-119.

Najafi-Tavani, S., Sharifi, H., \& Najafi-Tavani, Z. (2016). Market orientation, marketing capability, and new product performance: The moderating role of absorptive capacity. Journal of Business Research, 69(11), 5059-5064.

Orlandi, L. B. (2016). Organizational capabilities in the digital era: Reframing strategic orientation. Journal of Innovation \& Knowledge, 1(3), 156-161.

Pan, G., Pan, S.-L., \& Lim, C.-Y. (2015). Examining how firms leverage IT to achieve firm productivity: RBV and dynamic capabilities perspectives. Information \& Management, 52(4), 401-412.

Peppard, J., \& Ward, J. (2004). Beyond strategic information systems: towards an IS capability. The Journal of Strate-gic Information Systems, 13(2), 167-194.

Plattfaut, R., Niehaves, B., Voigt, M., Malsbender, A., Ortbach, K., \& Poeppelbuss, J. (2015). Service innovation per-formance and information technology: An empirical analysis from the dynamic capability perspective. International Journal of Innovation Management, 19(04).

Poolton, J., Ismail, H. S., Reid, I. R., \& Arokiam, I. C. (2006). Agile marketing for the manufacturing-based SME. Marketing Intelligence \& Planning, 24(7), 681-693.

Potdar, P. K., Routroy, S., \& Behera, A. (2017). Agile manufacturing: a system-atic review of literature and implications for future research. Benchmarking: An International Journal, 24(7), 2022-2048. 
Quaadgras, A., Weill, P., \& Ross, J. W. (2014). Management commitments that maximize business impact from IT. Journal of Information Technology, 29(2), 114-127.

Rai, A., \& Tang, X. (2010). Leveraging IT capabilities and competitive process capabilities for the management of interorganizational relationship portfolios. Information Systems Research, 21(3), 516-542.

Ravichandran, T. (2017). Exploring the relationships between IT competence, innovation capacity and organizational agility. The Journal of Strategic Information Systems.

Raymond, L., Bergeron, F., Croteau, A.-M., \& St-Pierre, J. (2015). Developing Absorptive Capacity through e-Business: The Case of International SMEs. Journal of Small Business Management, 53(S1), 75-94.

Reid, M., Hultink, E. J., Marion, T., \& Barczak, G. (2016). The impact of the frequency of usage of IT artifacts on pre-development performance in the NPD process. Information \& Management, 53(4), 422-434.

Roberts, N. (2015). Absorptive capacity, organizational antecedents, and environmental dynamism. Journal of Business Research, 68(11), 2426-2433.

Roberts, N., \& Grover, V. (2012). Leveraging information technology infrastructure to facilitate a firm's customer agility and competitive activity: An empirical investigation. Journal of Management Information Systems, 28(4), 231-270.

Saraf, N., Langdon, C. S., \& Gosain, S. (2007). IS application capabilities and relational value in interfirm partnerships. Information Systems Research, 18(3), 320-339.

Saunders, A., \& Brynjolfsson, E. (2016). Valuing Information Technology Related Intangible Assets. Mis Quarterly, 40(1).

Setia, P., \& Patel, P. C. (2013). How information systems help create OM capabilities: Consequents and antecedents of operational absorptive capacity. Journal of Operations Management, 31(6), 409-431.

Sharma, P., Davcik, N. S., \& Pillai, K. G. (2016). Product innovation as a mediator in the impact of $R \& D$ expenditure and brand equity on marketing performance. Journal of Business Research, 69(12), 5662-5669.

Song, M., Nason, R. W., \& Di Benedetto, C. A. (2008). Distinctive marketing and information technology capabilities and strategic types: A cross-national investigation. Journal of International Marketing, 16(1), 4-38.

Stoel, M. D., \& Muhanna, W. A. (2009). IT capabilities and firm performance: A contingency analysis of the role of industry and IT capability type. Information \& Management, 46(3), 181-189.

Takata, H. (2016). Effects of industry forces, market orientation, and marketing capabilities on business performance: An empirical analysis of Japanese manufacturers from 2009 to 2011. Journal of Business Research, 69(12), 56115619.

Tallon, P. P. (2008). Inside the adaptive enterprise: an information technology capabilities perspective on business pro-cess agility. Information Technology and Management, 9(1), 21-36.

Tan, F. T. C., Tan, B., Wang, W., \& Sedera, D. (2017). IT-enabled operational agility: An interdependencies perspective. Information \& Management, 54(3), 292-303.

Tarafdar, M., \& Qrunfleh, S. (2017). Agile supply chain strategy and supply chain performance: complementary roles of supply chain practices and information systems capability for agility. International Journal of Production Research, 55(4), 925-938. 
Teece, D. J., Pisano, G., \& Shuen, A. (1997). Dynamic capabilities and strategic management. Strategic Management Journal, 509-533.

Trainor, K. J., Andzulis, J. M., Rapp, A., \& Agnihotri, R. (2014). Social media technology usage and customer relation-ship performance: A capabilities-based examination of social CRM. Journal of Business Research, 67(6), 1201-1208.

Tsai, S.-P. (2015). Dynamic marketing capabilities and radical innovation commercialisation. International Journal of Technology Management, 67(2-4), 174-195.

van den Driest, F., \& Weed, K. (2014). The ultimate marketing machine. Harvard Business Review, 92, 54-63.

Vassileva, B. (2017). Marketing 4.0: How Technologies Transform Marketing Organization. Obuda University E-Bulletin, 7(1), 47.

Vinodh, S., Devadasan, S. R., Vasudeva Reddy, B., \& Ravichand, K. (2010). Agility index measurement using multi-grade fuzzy approach integrated in a 20 criteria agile model. International Journal of Production Research, 48(23), 7159-7176.

Wade, M., \& Hulland, J. (2004). The resource-based view and information systems research: Review, extension, and suggestions for future research. MIS Quarterly, 28(1), 107-142.

Wang, E. T., Hu, H.-F., \& Hu, P. J.-H. (2013). Examining the role of information technology in cultivating firms' dy-namic marketing capabilities. Information \& Management, 50(6), 336-343.

Wang, H.-M. D., \& Sengupta, S. (2016). Stakeholder relationships, brand equity, firm performance: A resource-based perspective. Journal of Business Research, 69(12), 5561-5568.

Wang, N., Liang, H., Zhong, W., Xue, Y., \& Xiao, J. (2012). Resource structuring or capability building? An empirical study of the business value of information technology. Journal of Management Information Systems, 29(2), 325-367.

Wang, Y., \& Hajli, N. (2017). Exploring the path to big data analytics success in healthcare. Journal of Business Re-search, 70, 287-299.

Wang, Z., \& Kim, H. G. (2017). Can Social Media Marketing Improve Customer Relationship Capabilities and Firm Performance? Dynamic Capability Perspective. Journal of Interactive Marketing, 39, 15-26.

Webster, J., \& Watson, R. T. (2002). Analyzing the past to prepare for the future: Writing a literature review. JSTOR.

Weigelt, C. (2013). Leveraging supplier capabilities: The role of locus of capability deployment. Strategic Management Journal, 34(1), 1-21.

Wilden, R., \& Gudergan, S. P. (2015). The impact of dynamic capabilities on operational marketing and technological capabilities: investigating the role of environmental turbulence. Journal of the Academy of Marketing Science, 43(2), 181-199.

Womack, J. P., \& Jones, D. T. (2010). Lean thinking: banish waste and create wealth in your corporation. Simon and Schuster.

Zhang, J., Jiang, Y., Shabbir, R., \& Du, M. (2015). Building industrial brand equity by leveraging firm capabilities and co-creating value with customers. Industrial Marketing Management, 51, 47-58.

Zhao, S., Zhao, S., Priporas, C.-V., \& Priporas, C.-V. (2017). Information technology and marketing performance within international market-entry alliances: A review and an integrated conceptual framework. International Marketing Review, 34(1), 5-28. 